\author{
G. Barone, E. Di Gristina, R. El Mokni \& G. Domina
}

\title{
Karyological data of four geophytes native to Tunisia
}

\begin{abstract}
Barone, G., Di Gristina, E., Mokni, R. El. \& Domina, G. 2021: Karyological data of four geophytes native to Tunisia [In Kamari, G., Blanché, C. \& Siljak-Yakovlev, S. (eds), Mediterranean plant karyological data-31]. - Fl. Medit. 31: 341-345. http://dx.doi.org/10.7320/FlMedit31.341

Chromosome numbers were studied in four geophytes collected in Tunisia. Allium pallens was collected from Zembra island, N of Tunisia, while Drimia purpurascens, Oncostema peruvianum and Pancratium foetidum from continental Tunisia. The chromosome numbers found for Allium pallens, Drimia purpurascens, and Oncostema peruvianum coincides with the previous reports obtained from other Mediterranean populations. The chromosome number $2 n=22$, found on material from Toujane is the first reported for Pancratium foetidum.
\end{abstract}

Keywords: Chromosome number, North Africa, Allium pallens, Drimia purpurascens, Oncostema peruvianum, Pancratium foetidum.

\section{Introduction}

In the course of floristic and biological investigations on the flora of Tunisia in the last 10 years, geophyte seeds and bulbs have been collected and cultivated at the Botanical Garden of Palermo. The karyological investigations on the cultivated plants enriches the knowledge on this peculiar flora. Monocotyledonous geophytes make up about 6 percent of the entire flora (cfr. El Mokni \& al. in press). Of these, 25 are endemic to Tunisia or to Tunisia and the surrounding countries (Domina \& El Mokni 2018). Although monocotyledonous geophytes are among the most investigated plants from the cariological point of view, the knowledge on this component of the flora of Tunisia is limited to a few contributions (Battaglia 1957; Hong 1982; García-Barriuso \& al. 2010; Ferjani \& al. 2015).

2000. Allium pallens L. $-2 n=4 \mathrm{x}=32$ (Fig. 1a).

Tn: Island of Zembra, hills above the village, $50 \mathrm{~m}$ a.s.1., $37.120615^{\circ} \mathrm{N}, 10.809218^{\circ} \mathrm{E}$, 10 May 2013, G. Domina (Hort. coll. PAL). 
Allium pallens L. (sect. Codonoprasum Rchb.) is a geophyte widespread in the Mediterranean area, in particular Portugal, Spain, Baleares, France, Italy, Sicily, Greece, Aegean Islands, Cyprus, W and S Turkey, Syria, Lebanon, Israel, Egypt, Tunisia, Algeria and Morocco. It is a synanthropic species, occurring in nitrophilous habitats as cultivated or abandoned fields (vineyards, olive-grove), roadsides, sometimes in natural environments as garigues, maquis and meadows where it flowers in early summer. A. pallens is a critical species, often taxonomically misidentified in the European and Mediterranean Floras. It is closely related to A. convallarioides Grossh., a diploid species linked to natural habitats, which can be considered its probable ancestor (Brullo \& al. 2003).

The chromosome number $2 n=4 \mathrm{x}=32$ (Fig. 1a), found here on material from the island of Zembra (Tunisia) coincides with the previous reports obtained in Italy (Marchi \& al 1974; Brullo \& al. 2003) and other Mediterranean countries (Tanker \& Kurucu 1979; Pastor 1985; Tzanoudakis 1999; Brullo \& al. 2003). Also the chromosome number $2 n=16$ is known for A. pallens (Pastor 1982; Ruíz Rejón \& al. 1986).

2001. Drimia purpurascens J. Jacq. $-2 n=2 \mathrm{x}=20$ (Fig. 1b).

Tn: Djebel Boukornine, $300 \mathrm{~m}$ a.s.1., 36.697365 N, 10.340933 E, 24 Mar 2014, G. Domina (Hort. coll. PAL).

Drimia purpurascens J. Jacq. is a critical species, often taxonomically misidentified in the Mediterranean Floras. The species was published by Jacquin (1812) on plants cultivated in Vienna (Austria), received by the Botanical Garden of Milan (Italy) with the name "Drimia undulata". The origin of those plants was unknown, but they were placed at the Vienna Botanical Garden along with South African bulbous plants, and it was implicitly assumed that they were native to southern Africa. From that time, D. purpurascens is widely accepted to be a synonym of $D$. elata Jacq., a species widespread from Sudan to South Africa. However, a nomenclatural and taxonomic study on the taxa of the Drimia undata group (Crespo \& al. 2020) made it possible to clarify the taxonomic position of D. purpurascens. In fact, a close examination of the illustration in the protologue of D. purpurascens (the only extant original material of that name) revealed important morphological differences that make the synonymization with $D$. elata incorrect. On the contrary, main morphological characteristics of D. purpurascens closely relate it to D. undata Stearn (Crespo \& al. 2020).

The chromosome number $2 n=2 \mathrm{x}=20$ (Fig. 1b), found here on material from Bou Kournine (Tunisia) does not agree with the number reported for Drimia elata $(2 n=18)$ by Cave (1957) and Fedorov (1974) but it coincides with the one reported by Martinoli (1949), Battaglia (1957) and Bartolo \& al. (1984).

2002. Oncostema peruvianum (L.) Speta $-2 n=2 \mathrm{x}=16$ (Fig. 1c).

Tn: Matmatat-Al-Qadimal, 400 m a.s.1., 33.539738 ${ }^{\circ}$ N, 9.989747 ${ }^{\circ}$ E, 29 Apr 2019, G. Domina \& R. El Mokni (Hort. coll. PAL). 
Oncostema peruvianum (L.) Speta is a geophyte whose distribution extends from South Africa, into Europe and Asia (Azizbekova \& al. 1997). It is an attractive floral species with excellent commercial potential. O. peruvianum have different chromosome numbers due to changes in the nucleolar chromosomes and polyploidy (Carmona $\&$ al. 1984).

The chromosome number $2 n=2 \mathrm{x}=16$ (Fig. 1c), found here on material from Matmatat-Al-Qadimal (Tunisia) is included in the variability $(2 n=14,2 n=15,2 n=16$, $2 n=28,2 n=32$ ) reported for the Oncostema peruvianum group (Battaglia 1949, 1950; Carmona \& al. 1984; Luque 1988).

2003. Pancratium foetidum Pomel $-2 n=2 \mathrm{x}=22$ (Fig. 1d).

Tn: Toujane, $550 \mathrm{~m}$ a.s.1., $33.460248^{\circ} \mathrm{N}, 10.139170^{\circ} \mathrm{E}, 29$ Apr 2019, G. Domina \& R. El Mokni (Hort. coll. PAL).

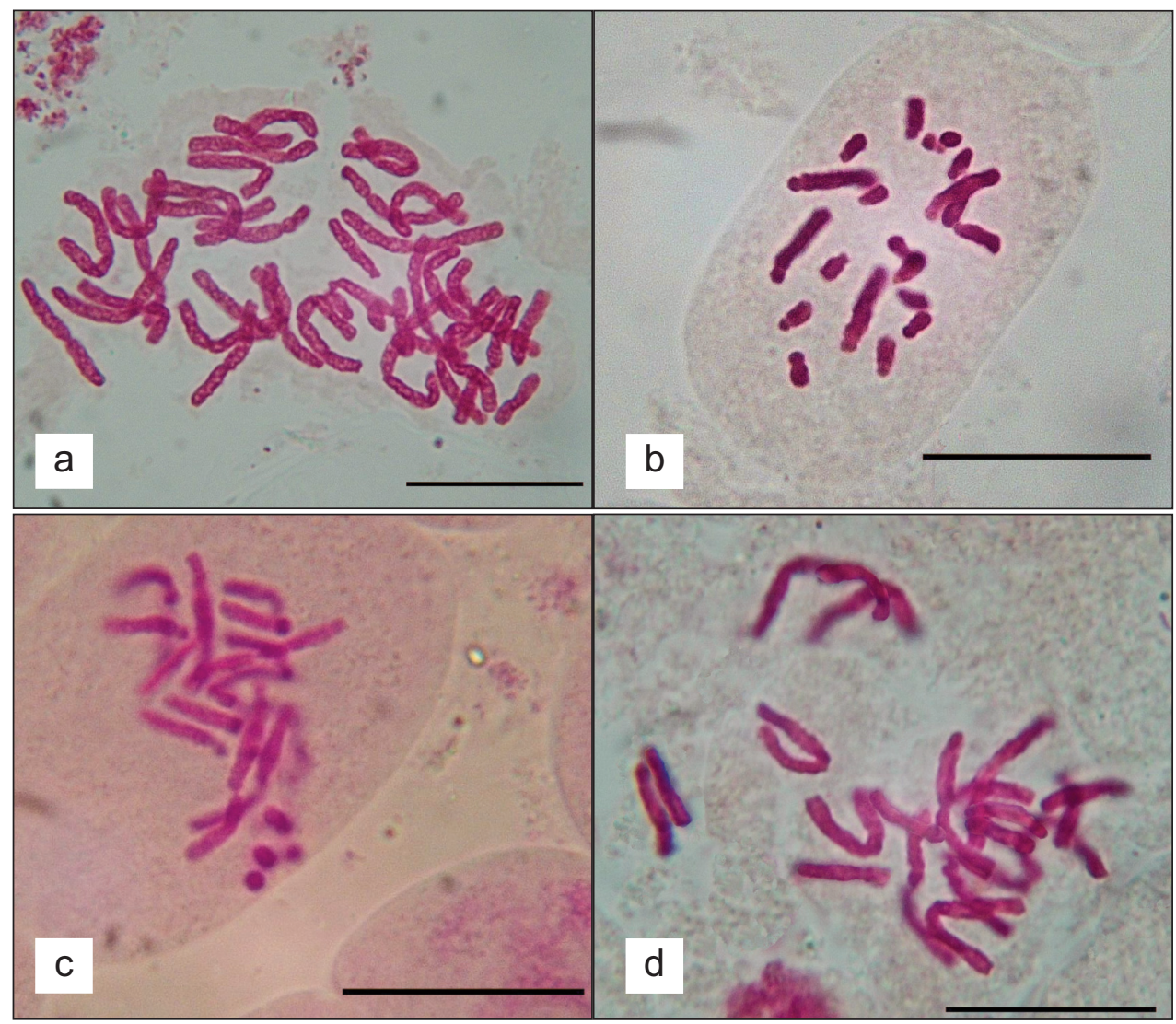

Fig. 1. Microphotographs of mitotic metaphase plates of: a, Allium pallens, $2 n=32 ; \mathbf{b}$, Drimia purpurascens, $2 n=20$; c, Oncostema peruvianum, $2 n=16$; d, Pancratium foetidum, $2 n=22$. - Scale bars: $10 \mu \mathrm{m}$. 
Pancratium foetidum Pomel is a geophyte native of NW-Africa, occurring from Morocco to Libya (El Gadi 1978). It was also found in Malta by Lanfranco \& Spiteri (2001). P. foetidum is vegetatively similar to $P$. maritimum to such an extent that the two species are indistinguishable in the field when not in flower or fruit. However, they can be easily separated during flowering or fruiting. In fact, the flowers of $P$. foetidum are considerably smaller compared to those of $P$. maritimum and furthermore, its flowers are foulsmelling in contrast to the fragrant flowers of P. maritimum. P. foetidum flowers mainly in Late September and October while $P$. maritimum flowers mainly in summer with only a brief overlap in the flowering period between the two species. P. foetidum has stamens about equal to the coronal teeth while in $P$. maritimum these are longer. The fruit in $P$. foetidum is oblong in contrast to the subglobular fruit of $P$. maritimum and carries much smaller seed (Lanfranco \& Spiteri 2001).

The chromosome number $2 n=2 \mathrm{x}=22$ (Fig. 1d), found here on material from Toujane (Tunisia) is the first report for this species.

\section{Acknowledgements}

The field work in Zembra was performed thanks to the contribution of APAL (Coastal protection and planning agency of Tunisia) and of the PIM (Small Mediterranean Island) Initiative coordinated by the Conservatoire du littoral (France). The collection in Djebel Boukornine was done during the $12^{\text {th }}$ OPTIMA Iter to Tunisia held in 2014 (Domina \& al. 2015).

\section{References}

Azizbekova, N., Roberts, C. M., Butland, S. \& Ellis B. 1997: Annual Growth and Development of Scilla peruviuana. - Hort. Sci. 32(3): 467-467.

Bartolo, G., Brullo, S., Pavone, P. \& Terrasi, M. C. 1984: Cytotaxonomical notes on some Liliaceae of N. Cyrenaica. - Webbia 38: 601-622.

Battaglia, E. 1949: Mutazioni cromosomiche in Scilla peruviana L. - Caryologia 1(2): 144-174.

- 1950: Mutazioni cromosomiche in Scilla peruviana L. - Caryologia 3(1): 126-147.

— 1957: Filogenesi del cariotipo nel genere Urginea. I-III: U. maritima (L.) Baker, U. fugax (Moris) Steinh. ed U. undulata (Desf.) Steinh. - Caryologia 9: 234-273.

Brullo, S., Guglielmo, A., Pavone, P. \& Salmeri, C. 2003: Cytotaxonomical remarks on Allium pallens and its relationships with $A$. convallarioides (Alliaceae). - Bocconea 16(2): 557-571.

Carmona, M. J., De Dominicis, R. I., Salvi, G. \& Maggini, F. 1984: Ribosomal RNA genes in biotypes of Scilla peruviana (Liliaceae). - Pl. Syst. Evol. 146: 1-11.

Cave, M. S. 1957: Index to Plant Chromosome Numbers for 1957. - Berkeley.

Crespo, M. B., Martínez-Azorín, M. \& Alonso, M. Á. 2020: The identity of Drimia purpurascens, with a new nomenclatural and taxonomic approach to the "Drimia undata" group (Hyacinthaceae=Asparagaceae subfam. Scilloideae). - Pl. Syst. Evol. 306: 67. https://doi.org/10.1007/s00606-020-01689-1

Domina, G. \& El Mokni, R. 2018: An inventory of the names of vascular plants endemic to C Mediterranean and described from Tunisia. - Phytotaxa 409(3): 105-128. https://doi.org/10.11646/phytotaxa.409.3.1

—, Greuter, W., Elyes Kchouk, M., El Mokni, R., Smaoui, A., Vitek, E., Bazan, G., Escobar, P. \& Raimondo, F. M. 2015: The 12th "Iter Mediterraneum" in Tunisia, 24 March - 4 April 2014. - Bocconea 27(1): 5-11 
El Gadi, A. 1978: Amaryllidaceae, Flora of Libya, 51. - Tripoli.

El Mokni, R., Barone, G., Maxted, N., Kell, S. \& Domina, G. in press: A Prioritised Inventory of Crop Wild Relatives and Wild Harvested Plants of Tunisia. - Genet. Res. Crop Evol.

Fedorov, A. A. (ed.) 1974: Chromosome numbers of flowering plants. - Leningrad.

Ferjani, H., Haouala, F. \& Mars, M. 2015: Morphological and karyological studies in two wild iris species (Iridaceae) of Tunisia. - Europ. Sci. J. 11(3): 175-185.

García-Barriuso, M., Sonia Bernardos, S. \& Amich, F. 2010: Chromosomal evolution in Mediterranean species of Ophrys sect. Pseudophrys (Orchidaceae): An analysis of karyotypes and polyploidy. - Taxon 59: 525-537.

Hong, D. 1982: Cytotype variation and polyploidy in Scilla autumnalis L. (Liliaceae). - Hereditas 97: 227-235.

Jacquin, J. F. 1812: Eclogae plantarum rariorum aut minus cognitarum, 1(3-4). - Vindobonae [Wien].

Lanfranco, E. \& Spiteri, H. J. 2001: New records for the Maltese flora: Pancratium foetidum Pomel (Family Amaryllidaceae). - Central Medit. Naturalist 3(3): 147-148.

Luque, T., Mejas, J. A. \& Daz Lifante, Z. 1988: Números cromosómicos para la flora española: 544550. - Lagascalia 15(1): 130-133.

Marchi, P., Carpineri, R. \& D'Amato, G. 1974: Numeri cromosomici per la flora italiana: 182-189. - Inform. Bot. Ital. 6(3): 303-312.

Martinoli, G. 1949: Ricerche citotassonomiche sui generi Urginea e Scilla della flora sarda. Caryologia 1(3): 329-357.

Pastor, J. 1982: Karyology of Allium species from the Iberian Peninsula. - Phyton 22(2): 171-200.

- 1985: Karyology of Allium stearnii and A. reconditum, two new species from the Iberian Peninsula. - Phyton 25(1): 73-76.

Ruíz Rejón, C., Lozano, R. \& Ruíz Rejón, M. 1986: Números cromosómicos para la flora española, 479-484. - Lagascalia 14(2): 292-296.

Tanker, N. \& Kurucu, S. 1979: Cytotaxonomical researches on some species of Allium naturally growing in Turkey. - J. Fac. Pharm. Ankara Univ. 9: 64-80.

Tzanoudakis, D. 1999: The genus Allium in Cyprus: a preliminary cytotaxonomical study. Bocconea 11: 105-115.

Addresses of the authors:

Giulio Barone ${ }^{1}$, Emilio Di Gristina ${ }^{1 *}$, Ridha El Mokni2 ${ }^{2,3}$ \& Gianniantonio Domina ${ }^{1}$, ${ }^{1}$ Department of Agricultural, Food and Forest Sciences, University of Palermo, Viale delle Scienze, Bldg. 4, I-90128 Palermo (Italy). E-mails: emilio.digristina@unipa.it; giuliobarone01@unipa.it; gianniantonio.domina@unipa.it

${ }^{2}$ University of Monastir, Laboratory of Botany, Cryptogamy and Plant Biology, Faculty of Pharmacy of Monastir, Avenue Avicenna, 5000-Monastir, Tunisia. E-mail: ridha.elmokni@fphm.rnu.tn.

${ }^{3}$ University of Carthage, IRESA, Laboratory of Forest Ecology, National Research Institute of Rural Engineering, Water and Forests, Ariana 2080, Tunisia

* corresponding author. 